\title{
Karakteristik Perusahaan dan Nilai Perusahaanpada Perusahaan yang Mengikuti CGPI Award Tahun 2011-2016
}

\author{
Samsul Rosadi ${ }^{1}$, Fahri Ali Ahzar ${ }^{2}$ \\ ${ }^{1}$ IAIN Surakarta \\ samsul.rosadi@gmail.com \\ ${ }^{1}$ IAIN Surakarta \\ paqriea@gmail.com
}

\begin{abstract}
This study discusses about companies that want to earn Earnings Per Share in Companies that Participate in the 2011-2016 CGPI Award. The characteristics of the company in this study are represented by company size, old company, old list, and leverage. The results of the F test show all simultaneous all independent variables on Earnings per Share. Based on the results of the test it can be concluded that the company is positive for Earning Per Share, while leverage has a negative effect on earnings per share. Old company and listing variables do not affect Earning per Share.
\end{abstract}

Keywords: company size, old company, old listing, and leverage, Earnings per Share

\begin{abstract}
Abstrak
Penelitian ini bertujuan untuk menguji pengaruh karakteristik perusahaanterhadap Earning Per Share pada Perusahaan yang Mengikuti CGPI Award Tahun 20112016.Karakteristik perusahaan dalam penelitian ini direpresentasikan dengan ukuran perusahaan, umur perusahaan, umur listing, dan leverage. Hasil uji $\mathrm{F}$ menunjukan bahwa secara simultan semua variabel independen berpengaruh terhadap Earning per Share. Berdasarkan hasil uji t dapat disimpulkan bahwa ukuran perusahaan berpengaruh positif terhadap Earning Per Share,sedangkan leverage berpengaruh negatif terhadap eraning per share. Variabel umur perusahaan dan umur listing tidak berpengaruh terhadap Earning per Share.

Kata Kunci: ukuran perusahaan, umur perusahaan, umur listing, dan leverage, Earning per Share
\end{abstract}

\section{PENDAHULUAN}

Keuntungan

pemilik

perusahaan tercermin dalam laba untuk para pemegang saham biasa atau yang sering disebut dengan Earning Per Share (EPS). EPS menunjukkan seberapa besar kemampuan perusahaan untuk memberikan pengembalian (return) kepada pemilik perusahaan. Dalam upaya mencapai tujuan tersebut, perusahaan membutuhkan dana untuk menjalankan bisnisnya, dalam hal ini perusahaan dapat menerapkan kebijakan pendanaan melalui utang dengan menanggung biaya yang bersifat tetap guna meningkatkan earning per share.

Setiap perusahaan satu dengan lainnya cenderung berbeda, hal ini dapat terjadi karena adanya faktor internal maupun eksternal perusahaan yang bersangkutan yaitu karakteristik masing-masing perusahaan yang berbeda-beda (Ulum et al, 2008 
).Kogan dan Tian (2012), karakteristik perusahaan meliputi ukuran perusahaan, leverage, likuiditas, penjualan pertumbuhan, pertumbuhan aset dan pergantian. Lainnya termasuk struktur kepemilikan, dewan karakteristik, usia perusahaan, pembayaran dividen, profitabilitas, akses ke pasar modaldan peluang pertumbuhan (McKnight dan Weir, 2008; Subrahmanyam dan Titman, 2001). Indonesian Institute for Corporate Governance (IICG) lahir pada Tanggal 2 Juni 2000 atas keinginan dari berbagai pihak yang diantaranya adalah dari Masyarakat Transparansi Indonesia (MTI); praktisi; tokoh masyarakat, yang memiliki pandangan yang sama atas masa depan Indonesia yang lebih baik. Tujuan membentuk IICG adalah untuk memasyarakatkan konsep corporategovernance dan manfaat penerapan prinsip GCG seluasluasnya dalam rangka mendorong terciptanya dunia usaha yang beretika dan bermartabat (IICG, 2017). Indeks CGPI adalah hasil program riset yang dilakukan secara terus menerus oleh IICG sejak Tahun 2001 dengan bekerja sama dengan majalah SWA. Tujuan diadakannya riset tersebut adalah untuk membuat pemeringkatan indeks terbaik dari setiap perusahaan yang menerapkan GCG (Tito \& Abdul, 2013).

Penelitian ini bertujuan untuk menguji secara empiris pengaruh karakteristik perusahaan terhadap nilai perusahaan. Penelitian ini menggunakan beberapa faktor karakteristik keuangan yang dapat mempengaruhi earning per share, yaitu ukuran perusahaan, umur perusahaan, umur listing perusahaan dan leverage. Ghareli dan Mohammadi (2016) melaporkan berbagai temuan untuk efekkarakteristik spesifik perusahaan pada kualitas pelaporan keuangan. Studi juga telah membuktikanpengaruh karakteristik perusahaan pada kinerja keuangan (Dioha et al., 2018). Misalnya, tegaskarakteristik seperti usia perusahaan (Swiss, 2008), ukuran perusahaan (Malik, 2011), likuiditas (Dogan, 2013)dan leverage (Mule dan Mukras, 2015) telah dikaitkan dengan profitabilitas.Studi terbaru oleh Foyeke et al. (2015) pada sampel perusahaan dari kedua keuangan dansektor non-keuangan di Nigeria mengungkapkan hubungan positif yang signifikan antara keuangankinerja dan ukuran perusahaan dengan tingkat pengungkapan tata kelola perusahaan

\section{KAJIAN TEORI DAN PENGEMBANGAN HIPOTESIS Signaling Theory}

Signalling theory menekankan kepada pentingnya informasi yang dikeluarkan oleh perusahaan terhadap keputusan investasi pihak di luar perusahaan. Informasi merupakan unsur penting bagi investor dan pelaku bisnis karena informasi pada hakekatnya menyajikan keterangan, catatan atau gambaran baik untuk keadaan masa lalu, saat ini maupun keadaan masa yang akan /dating bagi kelangsungan hidup suatu perusahaan dan bagaimana pasaran efeknya. 
Informasi yang lengkap, relevan, akurat dan tepat waktu sangat diperlukan oleh investor di pasar modal sebagai alat analisis untuk mengambil keputusan investasi.

Menurut

Jogiyanto

(2000:392), informasi yang

dipublikasikan sebagai suatu pengumuman akan memberikan signal bagi investor dalam pengambilan keputusan investasi. Jika pengumuman tersebut mengandung nilai positif, maka diharapkan pasar akan bereaksi pada waktu pengumuman tersebut diterima oleh pasar. Pada waktu informasi diumumkan dan semua pelaku pasar sudah menerima informasi tersebut, pelaku pasar terlebih dahulu menginterpretasikan dan menganalisis informasi tersebut sebagai signal baik (good news) atau signal buruk (bad news). Jika pengumuman informasi tersebut sebagai signal baik bagi investor, maka terjadi investor akan mempertimbangkan investasi pada perusahaan tersebut.

Ukuran Perusahaan dan Nilai perusahaan

$\begin{array}{rrr}\text { Ukuran } & \text { perusahaan adalah } \\ \text { suatu } & \text { skala } & \text { dimana dapat }\end{array}$ diklasifikasikan besar kecilnya perusahaan menurut berbagai cara antara lain dengan total aktiva, log size, nilai pasar saham, dan lain-lain. Besar kecilnya perusahaan akan mempengaruhi kemampuan dalam menanggung risiko yang mungkin timbul dari berbagai situasi yang dihadapi perusahaan (Prasetyorini, 2013). Perusahaan yang memiliki total aset yang relatif besar dapat beroperasi dengan tingkat efektivitas yang lebih tinggi dibandingkan dengan perusahaan yang memiliki total aset yang lebih rendah. Dengan adanya total aset yang besar ini menunjukkan kemampuan perusahaan dalam mengelola aset yang dimilikinya untuk menciptakan keuntungan. Sehingga, perusahaan dengan total aset yang besar akan lebih mampu untuk menghasilkan tingkat keuntungan yang tinggi, sehingga laba tersedia bagi pemegang saham biasa juga akan meningkat (Shinta dan Laksito, 2014). Dengan demikian, dapat disimpulkan bahwa semakin besar ukuran perusahaan maka akan semakin besar pula laba yang dihasilkan perusahaan bagi para pemegang saham

\section{Umur perusahaan dan nilai perusahaan}

Widiastuti

(2002:32), menyatakan bahwa umur perusahaan dapat menunjukkan bahwa perusahaan tetap eksis dan mampu bersaing. Loderer dan Waelchli (2010) menerangkan bahwa perusahaan akan menjadi tidak efisien seiring dengan berjalannya waktu. Perusahaan yang mengalami penuaan harus mengurangi biaya karena berbagai efek pembelajaran dalam perusahaan dan belajar dari perusahaan lain dengan industri yang sama maupun berbeda. Umur perusahaan dapat menunjukkan kemampuan dalam mengatasi kesulitan dan hambatan yang dapat mengancam kehidupan perusahaan, serta menunjukkan kemampuan perusahaan mengambil kesempatan dalam lingkungannya untuk 
mengembangkan usaha. Hasil penelitian Ilaboya dan Ohiokha (2016) menunjukkan umur perusahaan berpengaruh terhadap kinerja keuangan.

\section{Umur listing dan nilai perusahaan}

Barnes dan Walker (2006:56) perusahaan yang umur listingnya di bursa efek lebih muda akan berupaya untuk mendapatkan tambahan modal dengan semakin banyak mengungkapkan informasi perusahaan termasuk intellectual capital. Dapat diartikan bahwa perusahaan yang berumur lebih tua memiliki informasi yang lebih luas dan lebih berpengalaman dalam pengungkapan laporan keuangan, sehingga perusahaan dapat tetap eksis dan tetap dapat bersaing dengan perusahaan yang umurnya masih muda.

\section{Leverage dan nilai perusahaan}

Leverage mengacu pada proporsi hutang terhadap ekuitas dalam struktur modal perusahaan (Omondi dan Muturi, 2013). Leverrage berusaha untuk mengukur apa bagian dari total aset dibiayai oleh dana hutang. Rasio leverage digunakan untuk mengukur bisnis dan keuangan risiko perusahaan (Okwoli dan Kpelai, 2006. Omondi dan Muturi, (2013) leverage memiliki pengaruh negative, dari penelitian tersebut temuan ada bukti yang menyimpulkan bahwa sebagai perusahaan meningkatkan utang melebihi tingkat optimum, keuangan penurunan kinerja dan kemungkinan dapat meningkatkan kebangkrutan. Sedangkan menurut Putri dan Lestari (2014) berpengaruh negative terhadap nilai perusahaan.

METODE PENELITIAN

Populasi dan Sampel
Populasi dalam penelitian ini adalah semua perusahaan yang memperoleh pengahragaan CGPI yang terdaftar di Bursa Efek Indonesia pada tahun 2011-2015 yang berjumlah 40 perusahaan. Pengambilan sampel dalam penelitian ini menggunakan metode purposive sampling yaitu teknik pengambilan sampel dengan kriteria tertentu (Sekaran dan Bougie 2010: 285). Kriteria pengambilan sampel adalah sebagai berikut:
1. Perusahaan mendapatkan pengahragaan CGPI yang terdaftar di Bursa Efek Indonesia 2011-2015.

2. Perusahaan mendapatkan pengahragaan CGPI yang menerbitkan laporan tahunan (annual report) dan laporan keuangan (financial statement) padatahun 20112015.

\section{Definisi Operasional dan Definisi Pengukuran Variabel}

Variabel yang akan diteliti dalam penelitian ini diklasifikasikan menjadi dua, yaitu: variabel dependen dan variabel independen.

\section{a. Variabel Dependen}

Variabel dependen atau variabel terikat adalah variabel yang dijelaskan atau dipengaruhi oleh variabel independen atau variabel bebas (Sekaran dan Bougie, 2010: 126). Variabel dependen dalam penelitian ini adalah kinerja keuangan perusahaan.

\section{Nilai perusahaan}

dalam penelitian ini akan 
menggunakan proksi yaitu diukur dengan menggunakanearning per share.Earning Per Share atau pendapatan per lembar saham adalah pemberian keuntungan yang diberikan kepada peemgang saham dari setiap lembar yang dimilikiIrham Fahmi (2013:138). Adapun rumus earning per share (EPS) adalah:Earning After Tax atau Pendapatan setelah pajak dibagi jumlah saham beredar.

\section{b. Variabel Independen}

\section{Ukuran Perusahaan}

Adapun yang dimaksud total aktiva atau total aset adalah seluruh sumber daya yang dikuasaioleh perusahaan yang perolehannya didanai dari modal sendiri dan dari hutang. Ukuran perusahaan merupakan skala yang menentukan besar atau kecilnya perusahaan (Sudarmadji dan Sularto, 2007). Ukuran ini telah digunakan oleh dilambangkan dengan LNSIZE.

LNSIZE $=$ Logaritma Total Aset Perusahaan

\section{Umur Perusahaan}

Umur perusahaan dihitung sejak perusahaan tersebut berdiri berdasarkan akta pendirian sampai penelitian dilakukan. Umur perusahaan dalam penelitian ini diukur sesuai dengan penelitian yang dilakukan oleh Santioso dan Denova (2012) yaitu umur perusahaan dihitung sejak tahun perusahaan tersebut didirikan.

\section{Umur Listing Perusahaan}

Umur listing perusahaan diukur dengan penelitian Erna (2014) mengemukakan umur listing perusahaan merupakan seberapa lama perusahaan terdaftar di Bursa Efek
Indonesia (BEI) sebagai perusahaan go publik.

Leverage

Leverage yaitu kemampuan suatu perusahaan dalam memenuhi segala kewajiban finansialnya baik jangka panjang maupun jangka pendeknya. Dalam menghitung leverage dalam penelitian ini diproksikan dengan menggunakan dengan membagi total hutang dengan total asset. Adapun metode skala pengukuran Debt To Asset Ratio (DAR) sebagai alat penelitian sehingga dapat dirumuskan sebagai berikut dari penelitian yang dilakukan oleh Mehari dan Aemiro, (2013). Leverage $=$ total liabilitas dibagi total aset.

\section{Teknik analisis data}

Teknik analisis data dalam penelitian ini adalah menggunakan metode analisis regresi linear berganda denan model persamaam regresi sebagai berikut:

$\mathrm{Y}=\alpha+\beta_{1} \mathrm{X} 1+\beta_{2} \mathrm{X} 2+\beta_{3} \mathrm{X} 3+\beta_{4}$ $\mathrm{X} 4+\varepsilon$

Keterangan,

\begin{tabular}{|c|c|c|}
\hline Y & & arning Per \\
\hline Share & & \\
\hline$=$ & sta1 & $(\alpha)$ \\
\hline$\beta_{1,} \beta_{2,} \beta_{3,} \beta_{4}$ & $=$ & Koefisien \\
\hline Regresi $(\beta)$, & & \\
\hline $\mathrm{X} 1$ & $=$ & Ukuran \\
\hline Perusahaan, & & \\
\hline $\mathrm{X} 2$ & $=$ & Umur \\
\hline Perusahaan, & & \\
\hline X3 & $=$ & Umur \\
\hline Listing, & & \\
\hline $\mathrm{X} 4$ & & verage. \\
\hline$\varepsilon$ & $=0$ & \\
\hline
\end{tabular}

Sebelum dilakukan pengujian maka terlebih dahulu data harus lulus 


\begin{tabular}{cccc}
\hline \multicolumn{5}{c}{ Collinearity Statistics } \\
Model & B & ce & VIF \\
\hline $1 \quad \begin{array}{l}\text { (Consta } \\
\text { nt })\end{array}$ & 6009.841 & & \\
X1 & 523.739 & .184 & 5.432 \\
X2 & -.972 & .466 & 2.146 \\
X3 & -5.849 & .975 & 1.025 \\
X4 & - & & \\
& 1159.091 & & \\
& & & \\
\end{tabular}

a. Dependent Variable: Y

Sumber: data diolah 2018

Dari Tabel 3 dapat dilihat bahwa nilai tolerance masing-masing variabel independen yang digunakan dalam model regresi di penelitian ini memiliki nilai di atas 0,01 dan nilai VIF nya di atas 10 . Hasil pengujian ini mengindifikasikasn bahwa antar variabel dalam model regresi yang digunakan dalam penelitian ini tidak mengalami gajala multikolonieritas.

\section{Analisis Regresi Linier Berganda}

Dari hasil uji signifikasi simultan atau uji $\mathrm{F}$ terlihat dalam Tabel 7 variabel independen secara simultan berpengaruh signifikan terhadap variabel dependen. Hal ini dilakukan dengan membandingkan nilai besaran $\mathrm{F}$ hitung dengan $\mathrm{F}$ Tabel dan melihat nilai signifikasi Fnya. Dalam model regresi berganda yang menguji pengaruh variabel independen terhadap variabel dependen memiliki nilai sig $F$ nya $0,00^{\mathrm{a}}(0,000<0.05)$

ANOVA $^{b}$

\begin{tabular}{lrrrrrr}
\hline Model & Sum of Squares & df & Mean Square & F & Sig. \\
\hline 1 & Regression & 1967378.252 & 4 & 491844.563 & 8.252 & $.000^{\mathrm{a}}$ \\
& Residual & 2086056.315 & 35 & 59601.609 & & \\
\multicolumn{1}{l}{ Total } & 4053434.568 & 39 & & & \\
\hline
\end{tabular}

a. Predictors: (Constant), X4, X3, X2, X1

b. Dependent Variable: Y

Uji koefisien determinasi $\left(\mathrm{R}^{2}\right)$ ini digunakan untuk menguji goodnessfit model regresi. Koefisien determinasi $\left(\mathrm{R}^{2}\right)$ pada intinya digunakan untuk mengukur seberapa jauh kemampuan model dalam menerangkan variasi variabel dependen (Ghozali, 2011: 97).

Model Summary ${ }^{b}$

\begin{tabular}{|l|l|c|c|c|}
\hline $\begin{array}{c}\text { Mo } \\
\text { del }\end{array}$ & $\mathrm{R}$ & $\begin{array}{c}\mathrm{R} \\
\mathrm{Sq}\end{array}$ & $\begin{array}{c}\text { Adjus } \\
\mathrm{R} \mathrm{Sq}\end{array}$ & Std. Error \\
\hline 1 & $.697^{\mathrm{a}}$ & .485 & .427 & 244.13441 \\
\hline
\end{tabular}

a. Predictors: (Constant), X4, X3,

$\mathrm{X} 2, \mathrm{X} 1$

\begin{tabular}{|c|c|c|c|c|}
\hline \multicolumn{5}{|c|}{ Model Summary } \\
\hline $\begin{array}{l}\text { Mo } \\
\text { del }\end{array}$ & $\mathrm{R}$ & $\begin{array}{c}\mathrm{R} \\
\mathrm{Sq}\end{array}$ & $\begin{array}{c}\text { Adjus } \\
\mathrm{R} \mathrm{Sq}\end{array}$ & Std. Error \\
\hline 1 & $.697^{\mathrm{a}}$ & .485 & .427 & 244.13441 \\
\hline
\end{tabular}

Dari hasil uji koefisien determinasi dapat kita lihat bahwa nilai adjusted $\mathrm{R}$ square pada tabel 1 di atas yaitu 0,427 atau $42,7 \%$ hal ini menunjukkan bahwa variabel indipenden dalam penelitian ini dapat menjelaskan variabel dependen yaitu kinerja keuangan sebesar 42,7\%, 
sedangkan $37,3 \%$ dipengaruhi oleh

faktor lain.

\begin{tabular}{|c|c|c|c|c|c|c|}
\hline \multicolumn{7}{|c|}{ Coefficients $^{\mathrm{a}}$} \\
\hline & & \multicolumn{2}{|c|}{ Unstand. Coeff } & \multicolumn{3}{|l|}{ Stand. Coeff } \\
\hline \multicolumn{2}{|c|}{ Model } & B & Std. Error & Beta & $\mathrm{t}$ & Sig. \\
\hline 1 & (Constant) & -6009.841 & 1518.555 & & -3.958 & .000 \\
\hline & $\mathrm{X} 1$ & 523.739 & 125.781 & 1.177 & 4.164 & .000 \\
\hline & $\mathrm{X} 2$ & -.972 & 1.800 & -.096 & -.540 & .593 \\
\hline & $\mathrm{X} 3$ & -5.849 & 7.027 & -.102 & -.832 & .411 \\
\hline & $\mathrm{X} 4$ & -1159.091 & 475.557 & -.801 & -2.437 & .020 \\
\hline
\end{tabular}

Penelitian ini menggunakan variabel dependen yaitu Nilai perusahaanperaih penghargaan CGIP di Bursa Efek Indonesia tahun 20112015. Corporate Governance yang diproksikan dalam ukuran perusahaan, umur perusahaan, umur listing, dan leverage.

Dari hasil penelitian ini memberikan bukti empiris bahwa ukuran perusahaan dan leverage berpengaruh terhadap nilai perusahaan. Sedangkan umur perusahaan dan umur listing perusahaan tidak berpengaruh terhadap nilai perusahaan. Untuk lebih detailnya penjelasannya dijelaskan sebagai berikut:

\section{Ukuran Perusahaan Dan Nilai Perusahaan}

Dari hasil uji regresi variabel ukuran perusahaan mempunyai signifikasi sebesar 0,000 nilai signifikasi dari variabel ukuran perusahaan lebih kecil dari 0,05 sehingga variabelukuran perusahaan berpengaruh terhadap nilai

perusahaan dengan demikian hipotesis ukuran perusahaanberpengaruh terhadap nilai keuangan dinyatakan diterima. Semakin besar ukuran perusahaan semakin tinggi nilai perusahaan tersebut. Hasil penelitian ini sesuai dengan Hasil penelitian ini sejalan dengan hasil penelitian dari Gill dan Obradovich (2012) yang menyatakan bahwa Ukuran Perusahaan berpengaruh positif dan signifikan terhadap Nilai Perusahaan.

\section{Umur Perusahaan dan Nilai Perusahaan}

Dari hasil uji regresi variabel umur perusahaan mempunyai signifikasi sebesar 0,593 nilai signifikasi dari variabel umur perusahaan lebih besar dari 0,05 sehingga variabel umur perusahaan tidak berpengaruh terhadap nilai perusahaan dengan demikian hipotesis ditolak.Penelitian ini menemukan tidak adanya pengaruh antara umur perusahaan dan nilai perusahaan. Umur perusahaan digunakan untuk mengukur pengaruh lamanya perusahaan beroperasi terhadap profitabilitas perusahaan. Hasil penelitian ini sama dengan 
hasil penelitian dari Arisadi dan Djazuli (2013) dan hasil penelitian Putri dan Lestari (2014) menunjukkan bahwa umur perusahaan tidak berpengaruh terhadap nilai perusahaan tidak ditentukan oleh lamanya waktu perusahaan berdiri

\section{Umur listing Perusahaan dan Nilai Perusahaan}

Dari hasil uji regresi variabel umur listing perusahaan mempunyai signifikasi sebesar 0,411 nilai signifikasi dari variabel umur listing perusahaan lebih besar dari 0,05 sehingga variabel umur listing perusahaan tidak berpengaruh terhadap nilai perusahaan dengan demikian hipotesis ditolak.Penelitian ini menemukan tidak adanya pengaruh antara umur listing perusahaan dan nilai perusahaan. Umur perusahaan digunakan untuk mengukur pengaruh lamanya perusahaan beroperasi terhadap nilai perusahaan. Hasil penelitian ini tidak sama dengan hasil penelitian dari Penelitian oleh Puruwita (2012) menunjukkan bahwa umur listing berpengaruh terhadap luas pengungkapan sukarela perusahaan.Hasil penelitian ini sama dengan penelitian Bhuiyan dan Biswas (2007), dan Suta dan Laksito (2012) yang menunjukkan bahwa umur listing tidak berpengaruh terhadap pengungkapan corporate governance.

\section{Leverage Dan Nilai Perusahaan}

\begin{tabular}{lrr}
\multicolumn{2}{c}{ Dari hasil uji regresi } \\
variabel ukuran & perusahaan \\
mempunyai signifikasi sebesar 0,020 \\
nilai signifikasi dari & variabel \\
leverage lebih kecil & dari & 0,05 \\
sehingga & variabel & leverage \\
berpengaruh & terhadap & nilai \\
perusahaan & dengan & demikian
\end{tabular}

hipotesis leverageberpengaruh terhadap nilai perusahaan dinyatakan diterima. Semakin kecil leverage semakin tinggi nilai perusahaan tersebut. Hasil penelitian ini sesuai denganPutri dan Lestari (2014)yang menemukan bahwa leverage berpengaruh negative terhadap nilai perusahaan.

\section{KESIMPULAN DAN SARAN}

\section{Simpulan}

Nilai perusahaan menurut Brigham (2011:151) yaitu rasio harga pasar suatu saham terhadap nilai bukunya memberikan indikasi pandangan investor atas perusahaan. Perusahaan dipandang baik oleh investor yang artinya perusahaan dengan laba dan arus kas yang aman serta terus mengalami pertumbuhan, dijual dengan rasio nilai buku yang lebih tinggi dibandingkan perusahaan dengan pengembalian yang rendah. EarningPer Share atau pendapatan per lembar saham adalah pemberian keuntungan yang diberikan kepada peemgang saham dari setiap lembar yang dimiliki. Perusahaan yang memiliki karakteristik yang baik dan memperoleh penghargaan CGIP diproyeksikan mempunyai nilai EPS yang baik sehingga penelitian nini bertujuan untuk mengujikarakteristik perusahaan terhadap nilai perusahaan yang diukur menggunakan EPS. Hasil dari pengujian menunjukkan hasil sebagai berikut:

1. Ukuran perusahaan berpengaruh signifikan terhadap nilai perusahaan pada perusahaan penerima penghargaan CGIP yang terdaftar di BEI,.

2. Umur perusahaan tidak berpengaruh signifikan terhadap nilai perusahaan pada perusahaan penerima penghargaan CGIP yang terdaftar di BEI 
3. Umur listingperusahaan tidak berpengaruh signifikan terhadapnilai perusahaan pada perusahaan penerima penghargaan CGIP yang terdaftar di BEI.

4. Leverage berpengaruh signifikan terhadapnilai perusahaan pada perusahaan penerima penghargaan CGIP yang terdaftar di BEI.

\section{Saran}

Berdasarkan hasil analisis dan pembahasan pengujian hipotesis penelitian ini, maka dapat disampaikan beberapa saran bagi penelitian selanjutnya dengan tema sejenis sebagai berikut:

1. Membandingkan sampel perushaan yang memperoleh penghargaan CGIP dengan perusahaan lain yang terdaftar di BEI.

2. Menambahkan variabel lain dari karakteristik perusahaan sehingga diperoleh hasil yang lebih signifikan terkait dengan hubunganya dengan nilai perusahaan.

3. Untuk penelitian selanjutnya, peneliti memberikan saran menambah variabel independen lainnya, mengingat bahwa model regresi yang digunakan dalam penelitian ini hanya mampu menjelaskan sebesar $42,7 \%$ saja atas variabel dependen.

\section{REFERENSI}

Bhuiyan, Md Hamid Ullah and

P.K Biswas. 2007. Corporate

Governance And Reporting:

An Emperical Study of the

Listed Companies In

Bangladesh. Journal of

Business Studies. Vol.

XXVIII. No. 1.
Brigham, Eugene F. dan Houston, Joel F. 2011. Dasar-dasar Manajemen Keuangan Terjemahan. Edisi 10. Jakarta: Salemba Empat.

Dioha, C., Mohammed, N.A. and Okpanachi, J. (2018), "Effect of firm characteristics on profitability of listed consumer goods companies in Nigeria", Journal of Accounting, Finance and Auditing Studies, Vol. 4 No. 2, pp. 14-31.

Dogan, M. (2013), “Does firm size affect firm profitability? Evidence from Turkey", Journal of Finance and Accounting, Vol. 4 No. 4, pp. 53-59.

Erna Wati, Indriani, dkk. 2014.

"Faktor-Faktor yang

Mempengaruhi Luas

Pengungkapan Sukarela dan Implikasinya terhadap Asimetri Informasi”. Simposium Nasional Akuntansi XVII

Fahmi, Irham. 2013. "Pengantar Manajemen Keuangan”. Bandung : Alfabeta.

Foyeke, O.I., Iyoha, F.O. and Ojeka, S. (2015), "Firm size 
and financial performance: a

determinant of corporate

governance disclosure

practices of Nigerian

companies", Journal of

Accounting and Auditing:

Research \& Practice, Vol. 1

No. 2015, pp. 223-225.

Ghareli, S. and Mohammadi, A. (2016), "A study on the effect of macroeconomic variables and firm characteristics on the quality of financial reporting of listed firms in Tehran Stock Exchange", Journal of Fundamental and Applied Sciences, Vol. 8 No. 2, pp. 1777-1797.

Ghozali, I. (2013). Analisis multivariate dengan program SPSS. Cet. Ke-tujuh. Semarang: Badan Penerbit Universitas Diponegoro.

Gill, Amarjit dan Obradovich, John. 2012. The Impact of Corporate Governance and Financial Leverage on the Value of American Firms. InternationalResearch

Journal of Finance and Economics. ISSN 1450-2887 Issue 91.
Jogiyanto, 2000.Teori Portofolio dan Analisis Investasi, Edisi Kedua ,BPFE,

Kogan, L. and Tian, M. (2012), "Firm characteristics and empirical factor models: a data-miningVexperiment", International Finance Discussion Papers No. 1070

Malik, H. (2011), "Determinants of insurance companies' profitability: an analysis of insurance sector of

McKnight, P.J. and Weir, C. (2008), “Agency costs, corporate governance mechanisms and ownership structure in large UK publicly quoted companies: a panel data analysis", The Quarterly Review of Economics and Finance, Vol. 49 No. 2, pp. 139-158. 